formation in barley at the serine $\rightarrow$ pyruvate stage in addition to the earlier step(s) as in maize, indicating differences in strength of binding of pyridoxal phosphate to the enzymes in the two plant species studied.

These results are in agreement with an earlier observation (Shah \& Rogers, 1969) that, whereas isonicotinyl hydrazide inhibited the incorporation of radioactivity from $\left[2{ }^{14} \mathrm{C}\right]$ glyoxylate, $\left[2-{ }^{14} \mathrm{C}\right]$ glycine and $\left[{ }^{14} \mathrm{C}\right]$ formate into $\beta$-carotene of illuminated etiolated maize seedlings, it did not affect incorporation from $\left[\mathrm{U}-{ }^{14} \mathrm{C}\right]$ serine. In a further series of experiments related to the latter observations we have shown that incorporation of radioactivity from $\mathrm{L}-\left[3-{ }^{14} \mathrm{C}\right]$ serine into $\beta$-carotene of illuminated etiolated maize seedlings was extremely low but could be considerably enhanced by supplying the plants at the same time with glycine and formate or with isonicotinyl hydrazide and glycine. The studies indicate that serine supplied to intact plants may be subject to considerable interconversion into glycine before incorporation into pigments. Radioactivity at C-3 of the serine may be diluted out in this process by unlabelled $\mathbf{C}_{1}$ fragments present in situ. Inhibition of this interconversion by the presence of isonicotinyl hydrazide resulted in a 40 . fold enhancement of incorporation of C-3 of the added serine into carotenoids, whereas there was little effect on incorporation of radioactivity into sterols.

We are grateful to Dr S. P. J. Shah for his advice and help on some aspects of the work. H.M.H. is in receipt of a Science Research Council Studentship.

Kirk, J. T. O. (1968). Planta, Berl., 78, 200.

Marker, A. F. H. \& Whittingham, C. P. (1966). Proc. $R$. Soc. B, 165, 473.

Pritchard, G. G., Whittingham, C. P. \& Griffin, W. J. (1963). J. exp. Bot. 14, 28.

Rogers, L. J. \& Goodwin, T. W. (1970). In Function and Biochemistry of Cell Structures, p. 193. Ed. by Oparin, A. J. Moscow : Nauka.

Rogers, L. J., Shah, S. P. J. \& Goodwin, T. W. (1968). Photosynthetica, 2, 184.

Shah, S. P. J. \& Rogers, L. J. (1969). Biochem.J. 114, 395.

\section{A New Type of Bile Salt}

By G. A. D. Haslewood and L. Tökŕs. (Department of Biochemistry, Guy's Hospital Medical School, London S.E.1, U.K., and Syntex Research, Palo Alto, Calif. 94304, U.S.A.)

Bile of the very large freshwater teleost Arapaima gigas of the family Osteoglossidae was kindly given to us by Dr P. H. Greenwood. The bile salts showed on t.l.c. at least four major components, one corresponding in $R_{F}$ to taurocholate. Dioxan- trichloroacetic acid cleavage and separation on Celite gave two crystalline bile alcohols, 'arapaimol-A' and 'arapaimol-B', both showing an intense purple response in the Hammarsten (HCl) test. I.r. and n.m.r. spectroscopy showed that they had the same steroid nucleus; mass spectra indicated formulae $\mathrm{C}_{27} \mathrm{H}_{48} \mathrm{O}_{5}$ and $\mathrm{C}_{27} \mathrm{H}_{48} \mathrm{O}_{6}$ and a steroid nucleus containing four hydroxyl groups. Arapaimol-A with lead tetra-acetate consumed about 3g-atoms of oxygen/mol; it did not give an acetonide. N.m.r. spectra suggested $-\mathrm{CH}\left(\mathrm{CH}_{3}\right) \cdot \mathrm{CH}_{2} \cdot \mathrm{OH}$ and $-\mathrm{CH}\left(\mathrm{CH}_{2} \cdot \mathrm{OH}\right)_{2}$ for the terminal side-chain group of the molecules of arapaimol-A and -B respectively, and indicated that, if hydroxyl groups were at C-3, C-7 and C-12, the fourth hydroxyl group might be at C-1, C-2 or C-6. All these results pointed to the partial synthesis of $2 \beta, 3 \alpha, 7 \alpha, 12 \alpha$ tetrahydroxycholan-24-oic acids.

Methyl $7 \alpha, 12 \alpha$-diacetoxy-4 $\beta$-bromo-3-oxo-5 $\beta$ cholan-24-oate with sodium acetate-acetic acid gave a mixture containing methyl $2 \beta, 7 \alpha, 12 \alpha$ triacetoxy-3-oxo-5 $\beta$-cholan-24-oate (I), as expected from the work of Satoh, Takahashi, Aoki \& Hagitani (1969). Reduction of compound (I) with sodium borohydride, followed by hydrolysis, readily gave $2 \beta, 3 \alpha, 7 \alpha, 12 \alpha$-tetrahydroxy-5 $\beta$-cholan-24-oic acid (II), whose i.r. spectrum showed all the bands between 9.0 and $15.0 \mu \mathrm{m}$ of the arapaimols. The n.m.r. spectra of (II) showed the same chemical shifts for the C-18 and C-19 protons as found for the arapaimols. We conclude that arapaimols-A and -B are $5 \beta, 25 \xi$-cholestane- $2 \beta, 3 \alpha, 7 \alpha, 12 \alpha, 26$-pentol and $5 \beta$-cholestane- $2 \beta, 3 \alpha, 7 \alpha, 12 \alpha, 26,27$-hexol respectively.

After alkaline hydrolysis of the bile salts we obtained 'arapaimic acid', believed from i.r., n.m.r. and mass-spectral observations to be $2 \beta, 3 \alpha, 7 \alpha, 12 \alpha$ tetrahydroxy-5 $\beta, 25 \xi$-cholestan-26-oic acid, and $\mathrm{Dr}$ I. G. Anderson, by g.l.c., confirmed the presence of cholic acid.

$2 \beta$-Hydroxylation has not previously been observed in any bile salt, but is a feature of insect steroid hormones.

Satoh, Y., Takahashi, T., Aoki, T. \& Hagitani, A. (1969). Bull. chem. Soc. Japan, 42, 1465.

Regulation of Enzymes Gonverting L-Mandelate into Benzoate in Bacterium N.G.I.B. 8250

By A. Livingstone and C. A. Fewson. (Department of Biochemistry, University of Glasgow, Glasgow W.2, U.K.)

The conversion of L-mandelate into benzoate in bacterium N.C.I.B. 8250 involves the enzymes L-mandelate dehydrogenase, benzoylformate 